\title{
Reason and Unreason in Twenty-first Century Science
}

\section{Acknowledgements and Speaker Affiliations}

An invitation-only dialogue held from 11-13 December 2011, Christ's College, Cambridge University, UK

Supported by the Fundação Calouste Gulbenkian; Sir Ralph Kohn and the Royal Swedish Academy of Letters, History and Antiquities

\section{Acknowledgements and Speaker Affiliations}

\section{Convened by}

Dagfinn Follesdal (Oslo, Norway)

John Harris (Manchester, UK)

Herbert Huppert (Cambridge, UK)

Peter Lachmann (Cambridge, UK)

Lars Walloe (Oslo, Norway)

\section{Submissions}

Sheila Bird: Medical Research Council Biostatistics Unite, Cambridge, UK

John Broome: White's Professor of Moral Philosophy, Oxford University, UK

Tracey Browne: Director, Sense About Science, London, UK

David Colquhoun: Professor of Pharmacology, University College London, UK; creator of website 'Improbable Science'

George Coyne: Former Director of the Vatican Observatory. Since January 2012 McDevitt Chair of Religious Philosophy at Le Moyne College in Syracuse, New York, USA

David Hand: Senior Research Investigator and Emeritus Professor of Mathematics, Imperial College, London, UK; Chief Scientific Advisor Winton Capital Management Michael Hanlon: Freelance Science Journalist, London, UK

John Harris: Lord Alliance Professor of Bioethics and Director of the Institute for Science, Ethics and Innovation, Manchester University, UK 
Anthony Kenny: Oxford University, UK

Peter Lachmann: Emeritus Sheila Joan Smith Professor of Immunology, Cambridge University, UK

Onora O'Neill: Professor of Philosophy, Cambridge University, UK

Ingo Potrykus: Emeritus Professor of Plant Sciences, Institute of Plant Sciences, Swiss Federal Institute of Technology. Zurich, Switzerland

Roman Prymula: Dean of Faculty of Military Health Sciences, Chair of Department of Epidemiology in Hradec Kralove, Czech Republic, and Professor of Hygiene, Preventive Medicine and Epidemiology

Lewis Wolpert: Emeritus Professor in Cell and Developmental Biology, University College London, UK 